УДК 632.4:632.5:634.2

DOI: 10.30679 / 2219-5335-2018-2-50-136-147

ФИТОСАНИТАРНЫЙ МОНИТОРИНГ ЭНТОМОПАТОСИСТЕМ КАК СПОСОБ УПРАВЛЕНИЯ ПРОДУКЦИОННЫМ ПОТЕНЦИАЛОМ КОСТОЧКОВЫХ АГРОЦЕНОЗОВ

Прах Светлана Владимировна канд. биол. наук

старший научный сотрудник лаборатории защиты плодовых и ягодных культур e-mail: plantprotecshion@ yandex.ru

Мищенко Ирина Григорьевна младший научный сотрудник лаборатории защиты плодовых и ягодных культур e-mail: plantprotecshion@yandex.ru

Федеральное государственное бюджетное научное учреждение «Северо-Кавказский федеральный научный центр садоводства, виноградарства, виноделия», Краснодар, Россия

В результате исследований выявлены наиболее вредоносные энтомопатокомплексы косточковых культур, установлены сроки их появления, вредоносности, а также характер взаимодействия составляющих вредных видов друг с другом, что является необходимым для фитосанитарного мониторинга и понимания механизмов их структурных взаимодействий. Отмечено одновременное заражение побегов и листьев мучнистой росой и заселение сливовой опыленной тлей Hyaloplerus arundinis $\mathrm{F}$.

Во второй половине вегетации в насаждениях вишни и черешни выявлен энтомо- патокомплекс: «Coccomyces hiemalis Higgins. - Myzus cerasi F.». Отмечается тенденция на совместное заражение -заселение листьев черешни
UDC 632.4:632.5:634.2

DOI: 10.30679 / 2219-5335-2018-2-50-136-147

\section{PHYTOSANITARY MONITORING OF ENTOMO-PATHOSYSTEMS AS A REGULATION METHOD OF PRODUCTIVE POTENTIAL OF STONE AGRICAL CENOSES}

\author{
Prakh Svetlana Vladimirovna \\ Cand. Biol. Sci \\ Senior Research Assiciate \\ of Laboratory of Fruit \\ and Berry crops Protection \\ e-mail: plantprotecshion@yandex.ru
}

Mishchenko Irina Grigoryevna

Junior Research Assiciate of Laboratory of Fruit and Berry crops Protection e-mail: plantprotecshion@yandex.ru

Federal state budgetary

scientific institution

"North-Caucasian Federal

Scientific Center for Horticulture, Viticulture, Wine-making", Krasnodar, Russia

As a result of the research, the most harmful entomo-pato complexes of stone fruit crops were identified, the time of their appearance, the severity, and the nature of the interaction of harmful species, that is necessary for phytosanitary monitoring and understanding of the mechanisms of their structural interactions. There was simultaneous infection of shoots and leaves with powdery mildew and colonization of plum hyphae of Hyaloplerus arundinis $\mathrm{F}$. In the second part of the vegetation in the plantations of cherry and sweet cherry, an entomo-pathocomplex was identified as "Coccomyces hiemalis Higgins. - Myzus cerasi $\mathrm{F}$.". There is a tendency for joint infection of the sweet cherry leaves (Phyllosticta prunicola (Opiz.) 
(Phyllosticta prunicola (Opiz.) и Stephanitis pyri $\mathrm{F}$. кружковой молью, грушевым клопом, филлостиктозом.

Выявлена тенденция на закрепление в косточковых насаждениях патокомплексов: «коккомикоз клястероспориоз», «курчавость листьев клястероспориоз», что усиливает патогенность входящих в него грибов. На вишне альтернариоз развивается как самостоятельно, так и в составе грибных комплексов, в частности c Clasterosporium carpophilum Aderh. На плодах черешни встречаются грибы рода Alternaria sp., сливы - гриб Fumago vagans Pers, а также эпифитные грибы из рода Fusarium. На пораженных млечным блеском листьях всех косточковых культур отмечается развитие $\mathrm{Cl}$. carpophilum.

Из-за превышения в два и выше раза нормы осадков чаще встречается на плодах патокомплекс возбудителей Monilia fructigena Pers. и Botrytis cinerea Pers. Полученные данные мониторинга позволяют определить стратегию оптимизации фитосанитарного состояния косточковых насаждений и разработать методологические и практические подходы с целью управления продукционным процессом косточковых насаждений.

Ключевые слова: ЗАКОНОМЕРНОСТИ КОСТОЧКОВЫЕ КУЛЬТУРЫ, ЭНТОМО-ПАТОСИСТЕМЫ, ВОЗБУДИТЕЛИ, ВРЕДИТЕЛИ and Stephanitis pyri F. with a circle moth, pear bug, phyllostectosis.

The tendency to fix the pathocomplexes in the stone fruit orchards is revealed: "cocomicosis-clasterosporium", "leaf curliness-clasterosporium", and it increases the fungal pathogen activity. In cherry trees, the alternaria develops independently as well as in the composition of fungal complexes, in particular with Clasterosporium carpophilum Aderh.

There are Alternaria sp., fungi in the sweet cherry fruits, as Fumago vagans Pers - in the plumtree, as well as epiphytic fungi of the genus Fusarium. The development of $\mathrm{Cl}$. Carpophilum are on the leaves affected by milky lustre of all stone fruit crops. Because of the excess of two and more times the norm of precipitation is more common on the fruits of the pathogens complex of stimulants of Monilia fructigena Pers. and Botrytis cinerea Pers. The obtained monitoring data allow to determine the strategy for optimization of the phytosanitary condition of stone fruit plantations and to develop the methodological and practical approaches to manage the production process of stone fruit plantations.

Key words: REGULARITIES, STONE FRUIT CROPS, ENTOMO-PATHOSYSTEMS, AGENTS, VERMINS

Введение. Одной из закономерностей изменения функциональной структуры косточковых агроценозов под влиянием усиления воздействия средовых факторов является закрепление тенденции на формирование энтомо-патосистем и возрастание их значимости. Подмерзания, возвратные весенние холода, продолжительные высокотемпературные летние засухи, перепады температур с большой амплитудой в период покоя и другие воздействия ослабляют растение вплоть до прямых повреждений тканей, в 
Плодоводство и виноградарство Юга России № 50(02), 2018 г.

которые затем заселяются микроорганизмы различной трофической направленности [1]. Комплексные исследования закономерностей в энтомо- патоценозах косточковых культур в условиях изменения климата необходимы для разработки методологических подходов к созданию адаптивных систем защиты и ликвидации чрезвычайных фитосанитарных ситуаций [2].

Объекты и методы исследований. Объектами исследований являлись энтомо-микопатоценозы надземной части косточковых деревьев. Обследования проводились в различных агроэкологических зонах Краснодарского края с использованием общепринятых и адаптированных методик [3-6].

Обсужнение результатов. В меняющихся условиях среды особенно остро стоят вопросы антропогенного воздействия на живые системы. Функциональная структура многолетнего агробиоценоза представляет собой постоянное взаимодействие различных типов взаимоотношений между автотрофными и гетеротрофными организмами. Управлять напрямую этими процессами невозможно, их можно только модифицировать посредством внешнего продуманного воздействия - фитосанитарного мониторинга, сортового состава, удобрений, средств и методов защиты (Зубков, 2010). Результатом такой модификации должны стать сбалансированные биосистемы: сообщества грибов, насекомых, клещей различной трофической направленности с достаточной степенью устойчивости. Невысокая угроза со стороны вредных видов, и эффективная роль полезных организмов создает благоприятную биоценотическую обстановку, что является одним из существенных факторов стабильного производства плодов [7].

Отмеченная в 2015-2017 гг. общая для всех многолетних агроценозов приспособительная реакция, повышающая жизнеспособность и агрессивность энтомопатогенных систем, имеет тенденцию к закреплению и в косточковых насаждениях. Значительно отличаются доминанты типичных 
комплексов сосущих вредителей насаждений косточковых культур - это, прежде всего, тли, клещи, клопы, цикадки. Группа вредителей рассмотрена на примере тлей.

В афидокомплексах косточковых отмечены следующие виды тлей: тростниковая (Hyalopterus pruni Geoffr.), хмелевая (Phorodon humuli japonensis Takah.), вишневая (Myzus cerasi F.), персиковая (Myzodes persicae Sulz.) и сливовая опыленная (Hyaloplerus arundinis F.). Уточнена онтогенетическая приуроченность экономически значимой вредоносности этих фитофагов, что объединяет их с растительноядными клещами на других культуpax: тли наносят большой вред молодым распустившимся листьям вишни, сливы в течение мая, июня и первой половины июля. Следовательно, между ними проявляется выраженная пищевая конкуренция [8].

При выпадении большого количества осадков в мае-июне у возбудителя мучнистой росы Podosphaera tridactyla de Bary отмечена тенденция на активное заражение молодых побегов сливы. Выявлено одновременное заражение побегов и листьев мучнистой росой и заселение сливовой опыленной тлей (Hyaloplerus arundinis F.) (рис. 1).

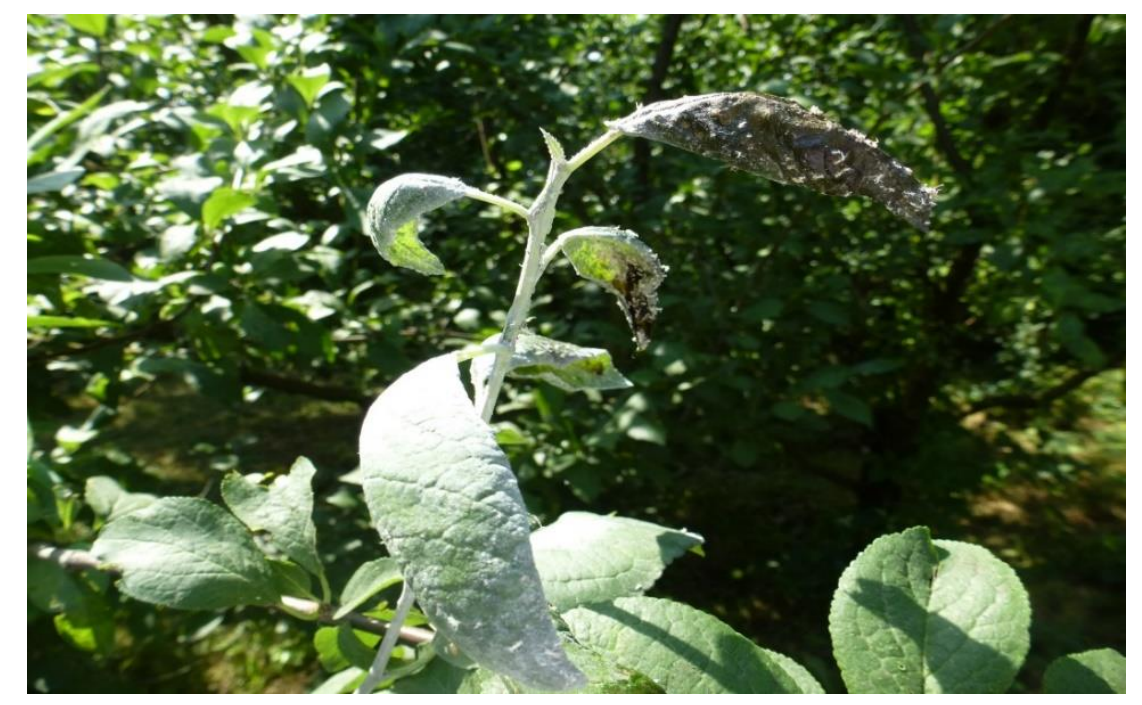

Рис. 1. Podosphaera tridactyla de Bary. - Hyaloplerus arundinis F.

Поражение мучнистой росой не только не снижало численность вредителя, но и благоприятствовало его развитию в связи с тем, что мучнистая роса 
Плодоводство и виноградарство Юга России № 50(02), 2018 г.

является облигатным паразитом, у которого мицелий является поверхностным и не препятствует питанию вредителя. На листьях вишни отмечается повреждение вишневым слизистым пилильщиком и поражение коккомикозом (рис. 2)

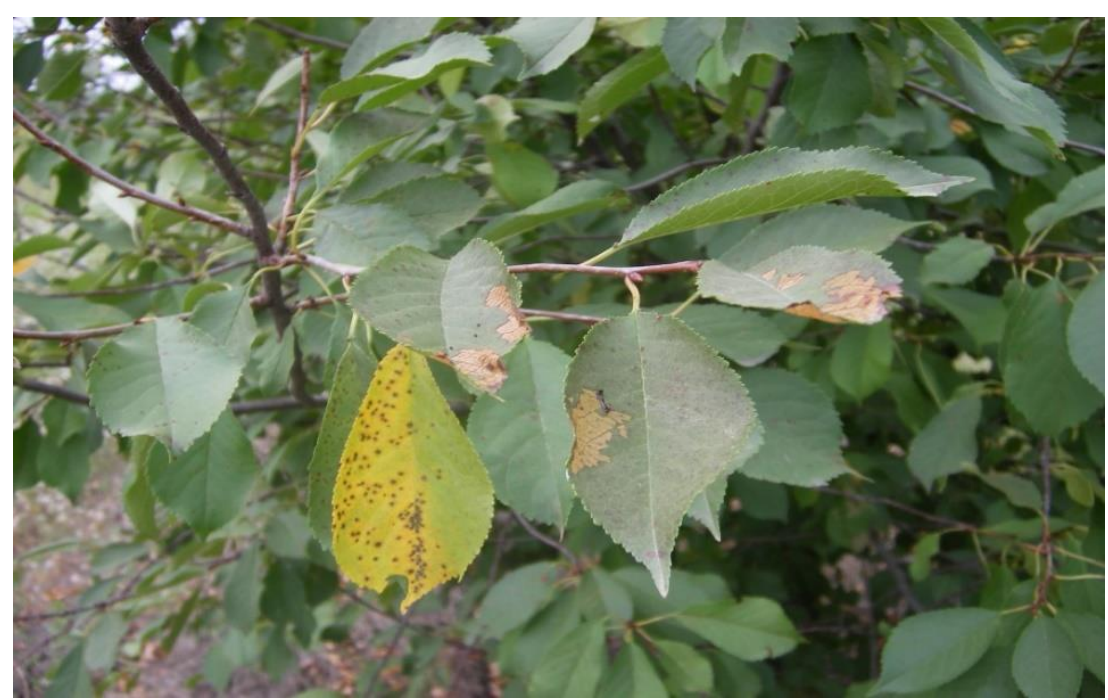

Рис. 2. Coccomyces hiemalis Higgins. - вишневый слизистый пилильщик Caliroa limacina Retz.

В период формирования завязи и роста плодов на поврежденных долгоносиком плодах выявлены грибы из рода Cladosporium. Возбудители монилиальной и серой гнилей начинают интенсивно развиваться в результате повреждения насекомыми (листовертка, плодожорка, долгоносики) плодов (рис. 3).

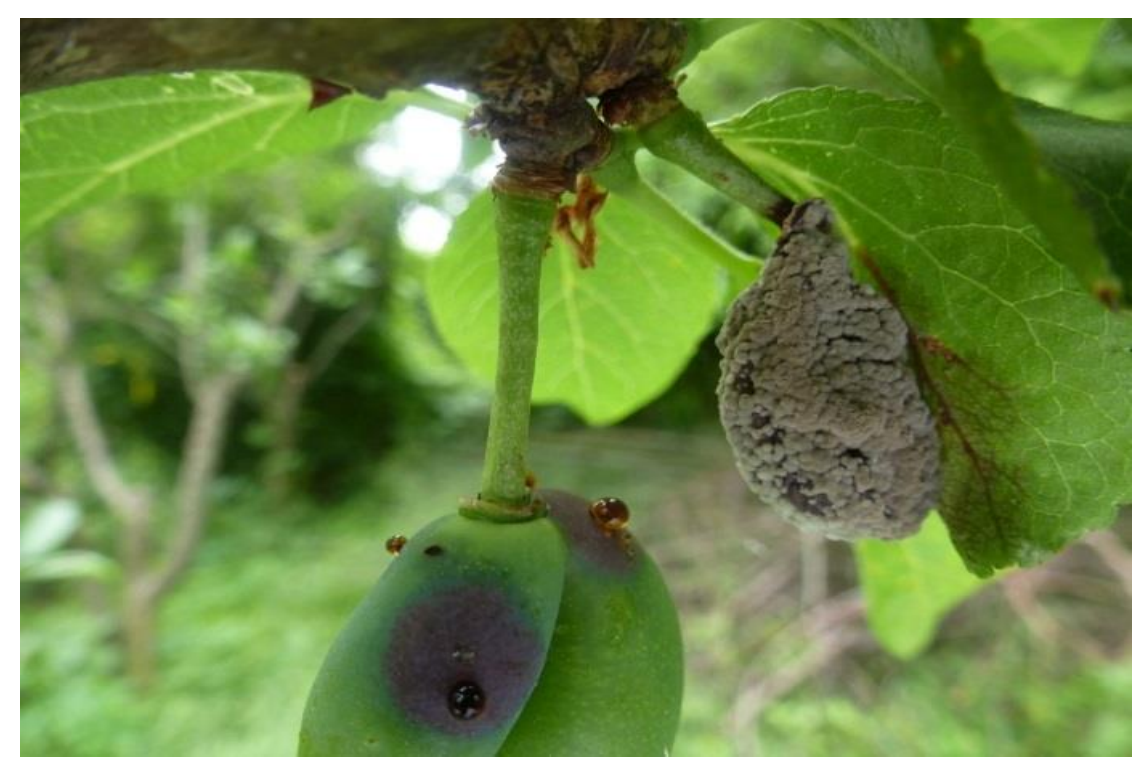

Рис. 3. Повреждение плодов долгоносиками и поражение Monilia fructigena Pers. - и Botrytis cinerea Pers. 
Плодоводство и виноградарство Юга России № 50(02), 2018 г.

Во второй половине вегетации, когда происходит минимизация защитных мероприятий, в насаждениях черешни и вишни наблюдается нарастание вредоносности вишневой тли и интенсивности развития коккомикоза (рис. 4), на сливе - ржавчины и грушевого клопа (Puccinia Tranzschelia pruni - spinosae Pers.- Stephanitis pyri F.) (рис. 5).

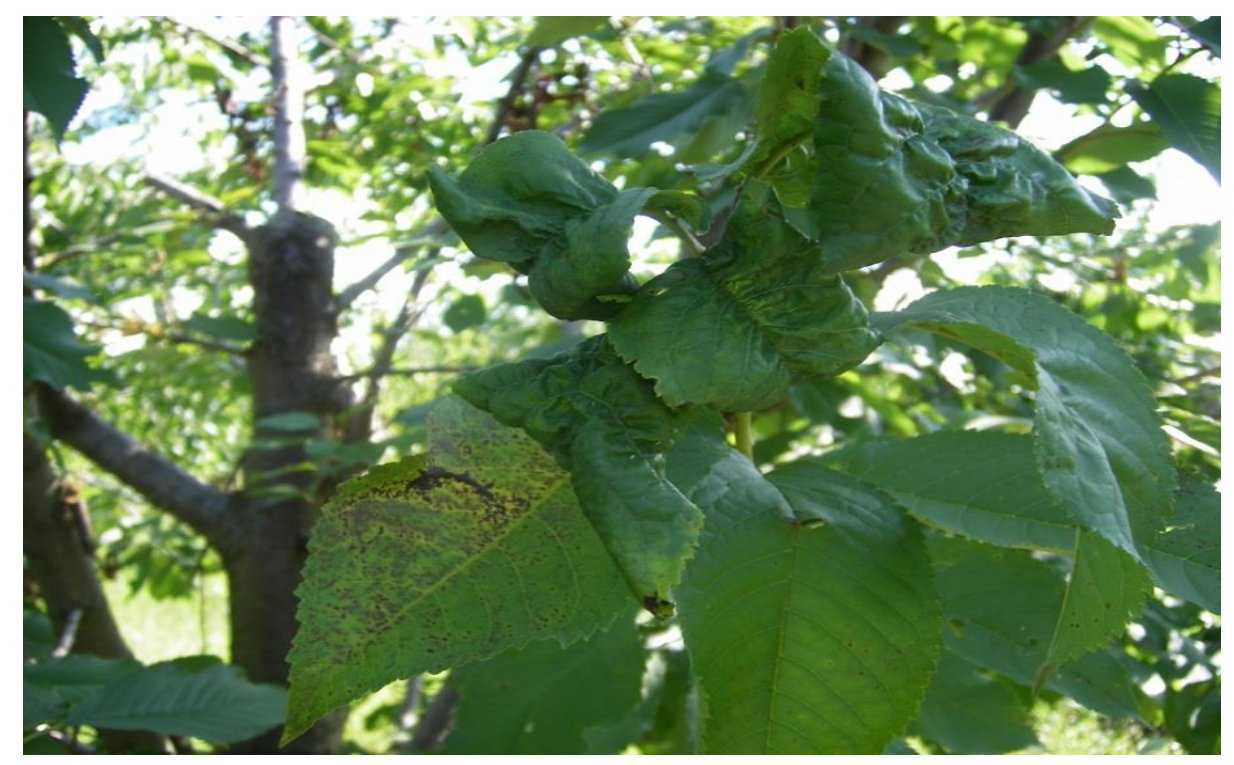

Pис. 4. Coccomyces hiemalis Higgins. - тля Myzus cerasi F. на листьях черешни

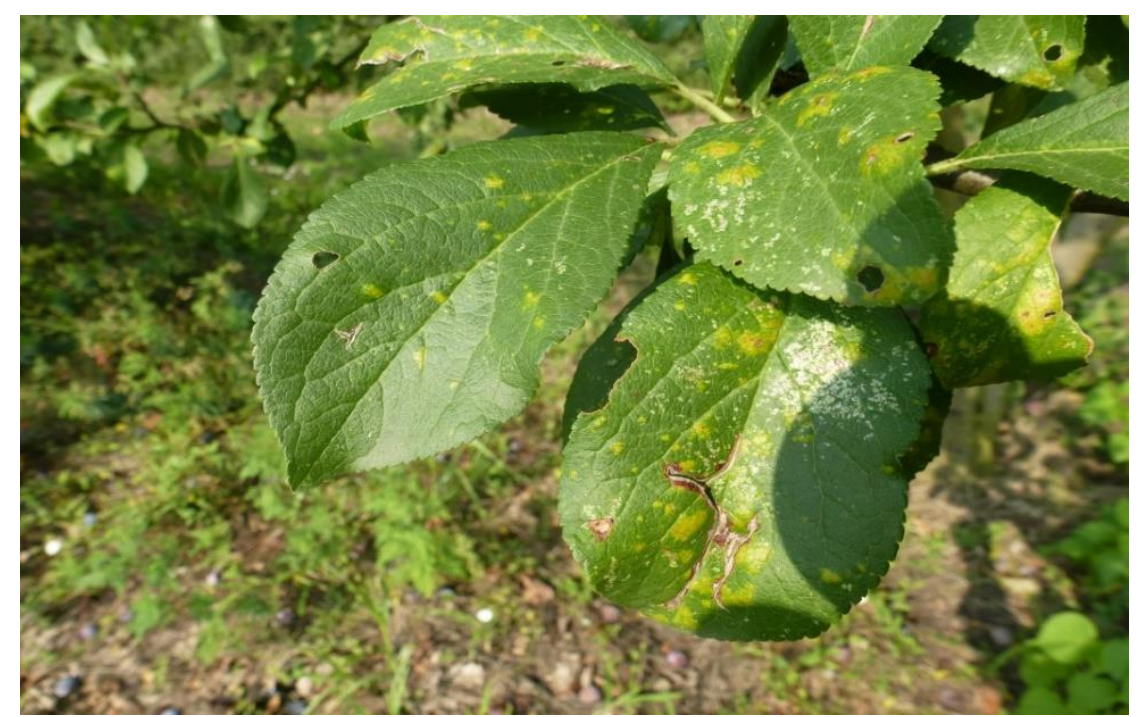

Рис. 5. Puccinia Tranzschelia pruni-spinosae Pers.- Stephanitis pyri $\mathrm{F}$.

На черешне наблюдается расширение видового состава второстепенных вредителей: боярышниковой кружковой моли и нижнесторонней мини- 
рующей моли. Максимальная вредоносность их отмечается во второй половине вегетации. В этот период наблюдается тенденция на совместное заражение - заселение листьев черешни грушевым клопом-филлостиктозом и кружковой молью-грушевым клопом-филлостиктозом (рис. 6, 7).

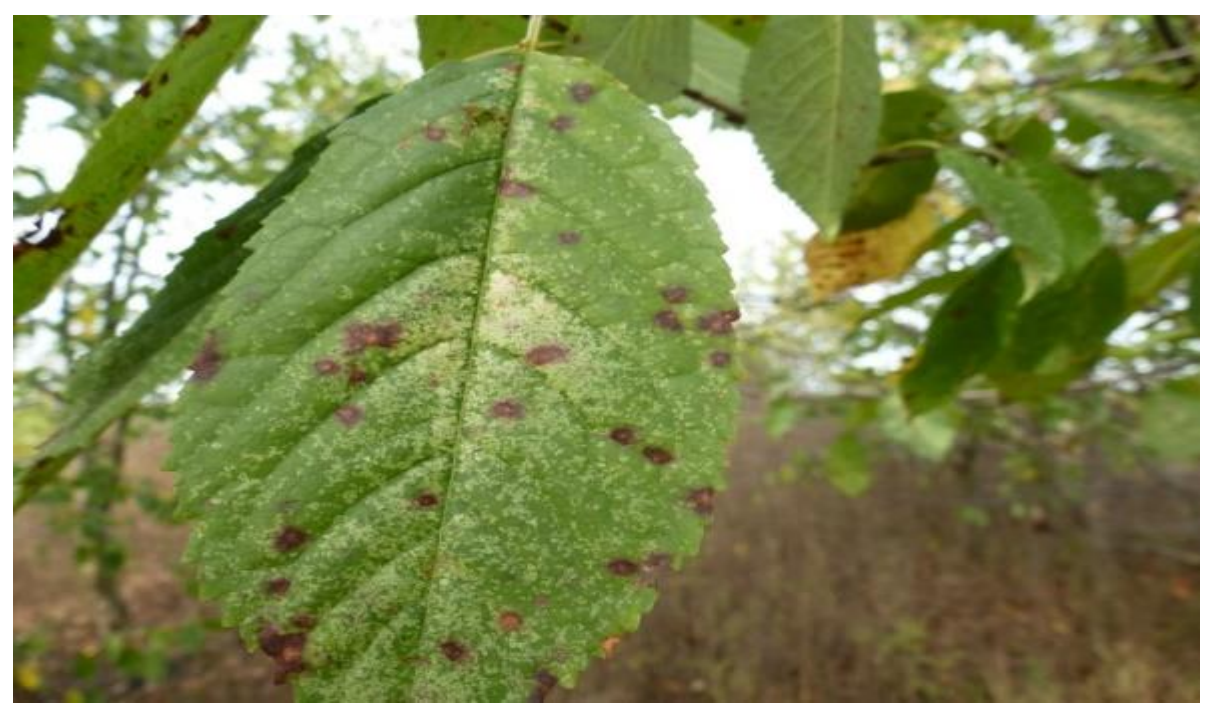

Рис. 6. Phyllosticta prunicola (Opiz.) и Stephanitis pyri F. на листьях черешни

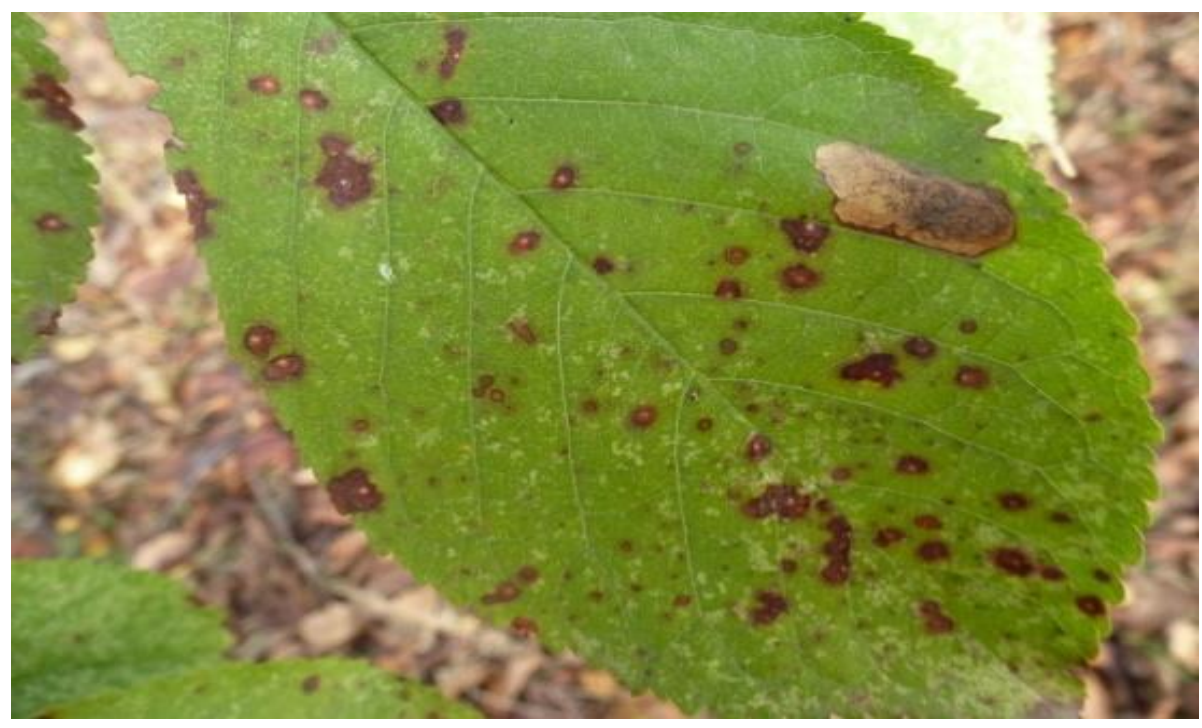

Рис. 7. Leucoptera malifoliella Costa. - Stephanitis pyri F. Phyllosticta prunicola Opiz.

Подтверждена закономерность на закрепление в косточковых насаждениях патокомплексов: «коккомикоз - клястероспориоз», «курчавость листьев - клястероспориоз», «филлостиктоз-коккомикоз», что усиливает патогенность входящих в него грибов (в силу антагонистических взаимодей- 
ствий токсины смешанной микробиоты являются более мощными и усугубляют стрессорное состояние растений [9].

У возбудителя цитоспороза косточковых Cytospora sp. наблюдается увеличение распространения и вредоносности с единичных проявлений до 10-15 \%, в первую очередь за счет поражения ослабленных абиотическими стрессами растений. Типичным для этого возбудителя становится формирование патокомплексов с наиболее часто встречаемыми возбудителями стволовых гнилей, что стимулирует рост дереворазрушающих грибов, увеличивает вероятность заболевания и ускоряет развитие патологического процесса [10].

На ветвях вишни отмечен комплекс Cryptosporiopsis corticola (Edg.) Nannf.) - Fumago vagans Pers. Также наблюдается смешенная инфекция Fusarium sporotrichioides Bilai.- Monilia cinerea Bonord., Taphrina pruni Tul Monilia (рис. 8, 9).

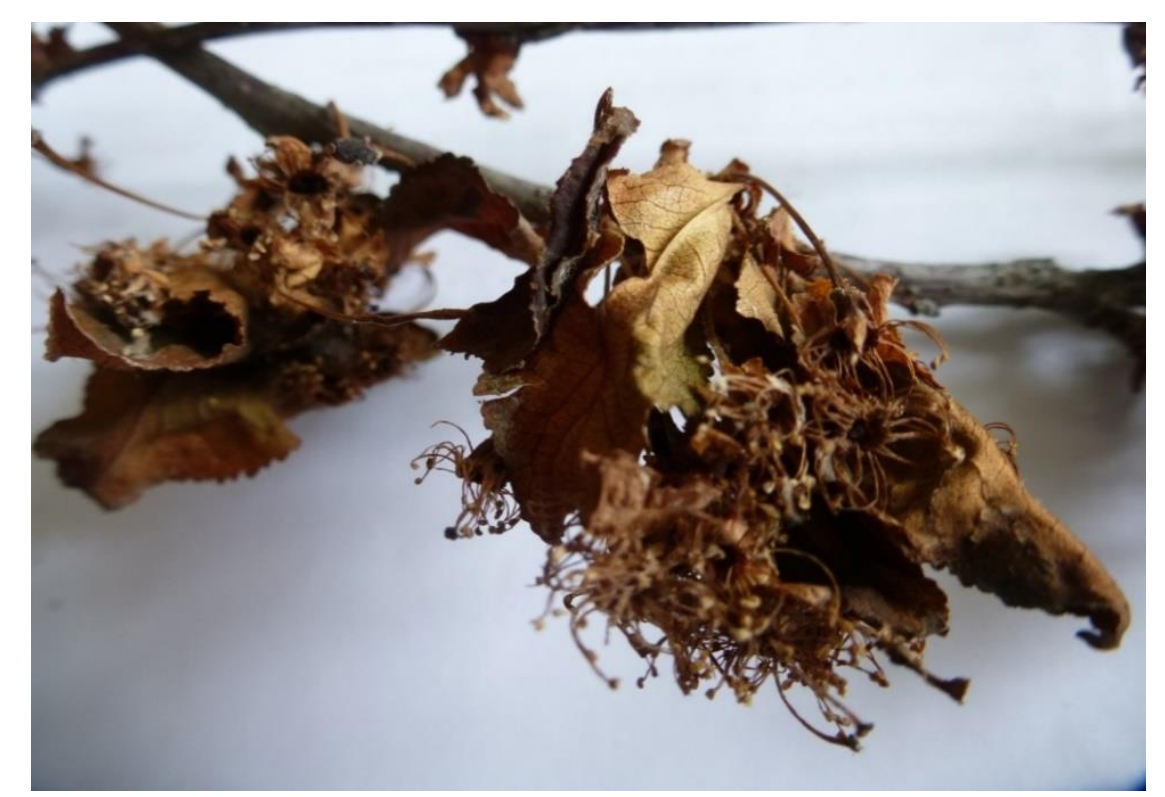

Pис. 8. Fusarium sporotrichioides Bilai. - Monilia cinerea Bonord.

На фоне подмерзания происходит заражение всех косточковых культур грибами рода Stereum, развивающимися в их древесине. На пораженных млечным блеском листьях отмечается развитие $C$. carpophilum. до $10 \%$. Деревья при этом постепенно ослабляются, урожай снижается [11]. 


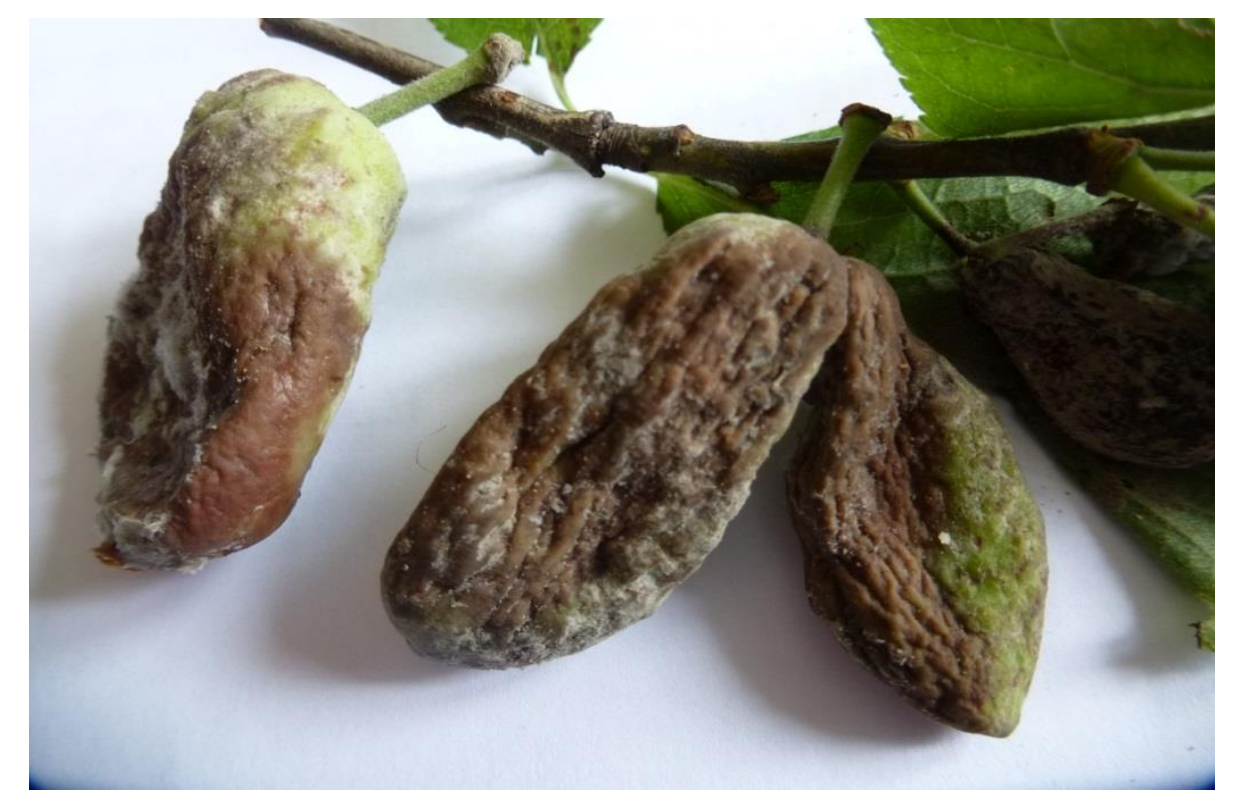

Рис. 9. Monilia и Taphrina pruni Tul.

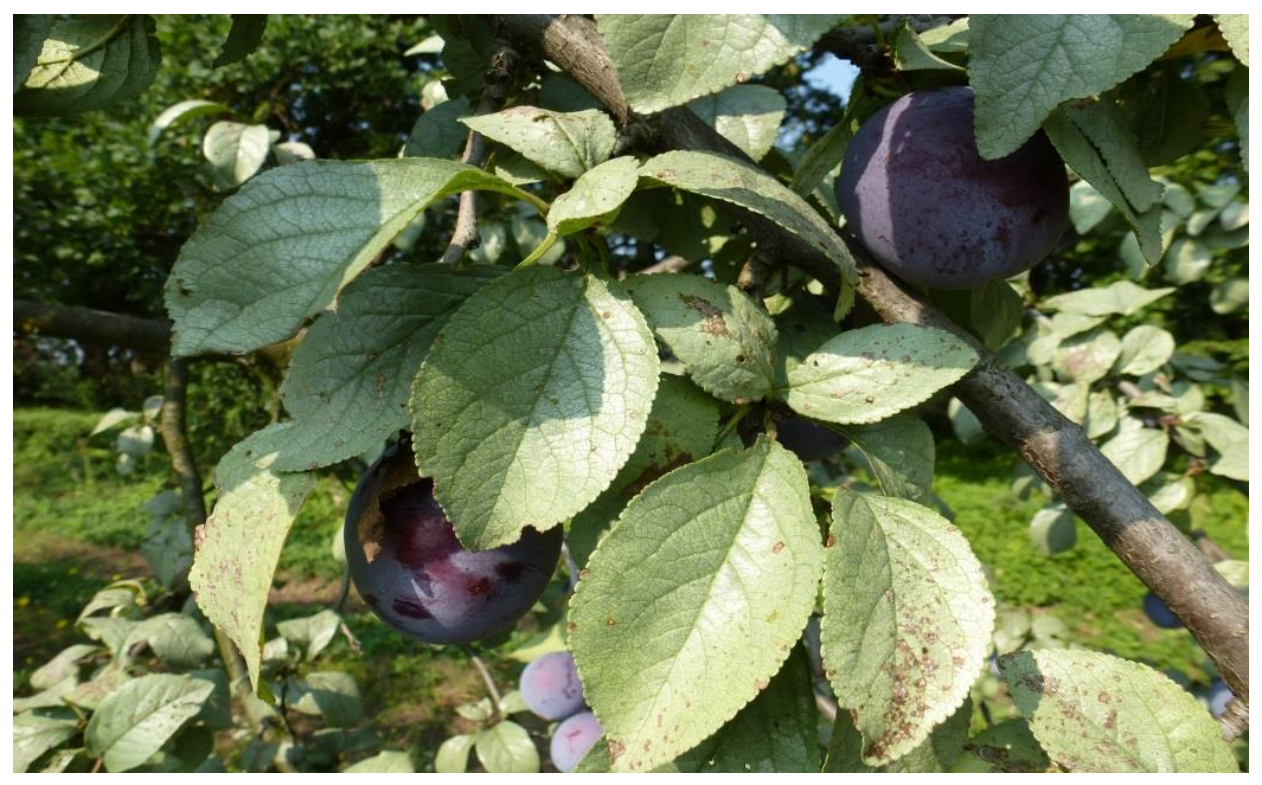

Рис. 10. Clasterosporium carpophilum (Lev). Aderh. Stereum purpureum (Pers.)Fr. на листьях сливы

В условиях региона биологические особенности возбудителя альтернариоза вишни сходны с биологией патогена на яблоне [12]. На листьях альтернариоз развивается как самостоятельно, так и с Clasterosporium carpophilum Aderh., особенно на ослабленных после морозов деревьях. Срок появления комплекса - август-сентябрь, локализация - листья. Симптомы поражения - часто сливающиеся пятна и занимающие более 50 \% поверхности листа. Установлен фактор, ускоряющий течение патологического 
процесса и скорость инфекции: средняя температура воздуха $+16 \ldots+21^{\circ} \mathrm{C}$, максимальная $+27 \ldots+36^{\circ} \mathrm{C}$. Под влиянием абиотических и биотических факторов происходит переход от сапротрофной фазы существования Alternaria в микопатоценозе вишни к полусапротрофной фазе [13, 14].

На плодах косточковых культур из-за превышения в два и выше раза нормы осадков чаще встречается патокомплекс возбудителей Monilia fructigena Pers. - и Botrytis cinerea Pers., чем инфицирование каждым из них по отдельности.

Образование патокомплексов грибов на генеративных и вегетативных органах косточковых культур происходит гораздо активнее при ослаблении растений под продолжительным воздействием экстремально высоких температур в сочетании с засухой, также на их образование влияет стрессовое состояние растений-хозяев из-за подмерзания, трофическая конкуренция и обилие осадков [9].

Bbыводы. В результате исследований установлено, что происходящие изменения в развитии вредных организмов обусловливают необходимость регулярного мониторинга фитосанитарного состояния косточковых насаждений. Знания, полученные на основе мониторинга энтомо-, патосистем, являются важной основой для контроля вредных объектов косточковых агроценозов в меняющихся средовых условиях. Полученные данные позволяют определить стратегию оптимизации фитосанитарного состояния и разработать методологические и практические подходы к управлению продукционным процессом косточковых насаждений.

\section{Литература}

1. Юрченко. Е.Г. Экологическое обоснование совершенствования фитосанитарного менеджмента для повышения устойчивости многолетних агроценозов / Е.Г. Юрченко, Г.В. Якуба, С.Р. Черкезова, С.В. Прах, Н.А. Холод, И.Г. Мищенко // Научные труды СКЗНИИСиВ.- Том 7. - Краснодар: СКЗНИИСиВ, 2015. - С.167-177. 
Плодоводство и виноградарство Юга России № 50(02), 2018 г.

2. Долженко, В.И. Фитосанитарное районирование вредных для сельского хозяйства организмов / В.И. Долженко // Агротехнический метод защиты растений от вредных организмов: материалы V междунар. научн.-практ. конф. (- Краснодар, 2011. - С. 24-30.

3. Методы определения болезней и вредителей сельскохозяйственных растений. - М.: Агропромиздат, 1987. - 224 с.

4. Методики опытного дела и методические рекомендации СКЗНИИСиВ. Краснодар, 2002. - С. 143-176.

5. Доспехов, Б.А. Методика полевого опыта / Б.А. Доспехов. - М.: Агропромиздат, 1985. - $351 \mathrm{c.}$

6. Пидопличко, Н.М.Грибы-паразиты культурных растений. Определитель в 3-х томах / Н.М. Пидопличко. - Киев: Наукова думка, 1977. - Т. 2. - 299 с.

7. Юрченко, Е.Г. Урожайность и качество виноградо-винодельческой продукции при применении биологизированной защиты от оидиума / Е.Г. Юрченко, О.П. Антоненко, Н.П. Грачева, В.Н. Ничипоренко // Плодоводство и ягодоводство России. 2011. - T. 23. - C. 336-343.

8. Бунцевич, Л.Л. Совершенствование системы производства высококачественного безвирусного посадочного материала плодовых и ягодных культур / Разработки, формирующие современный облик садоводства / Л.Л. Бунцевич, М.А. Костюк, Е.Н. Палецкая. - Краснодар: ГНУ СКЗНИИСиВ. - 2011. - С. 254-275.

9. Мищенко, И.Г. Мониторинг энтомо - патокомплексов косточковых культур в условиях южного садоводства России / И.Г. Мищенко, С.В. Прах. // Аграрная Россия. 2016. - №12. - 7-10.

10. Прах, С.В. Мониторинг энтомо-патоценозов косточковых культур как научная основа технологии защитных мероприятий /С.В. Прах, И.Г. Мищенко // Плодоводство и ягодоводство России: сборник научных работ. - М.: ФГБНУ ВСТИСП, 2017. T. XLIX. - C. 265-270.

11. Мищенко, И.Г. Изменения в структуре микопатокомплексов плодовых культур Краснодарского края в современных средовых условиях / И.Г. Мищенко, Г.В. Якуба // Современные направления использования генофонда культурных растений для устойчивого сельского хозяйства. К 115-летию со дня рождения академика ВАСХНИЛ М.С. Дунина. - Москва, 2016. - Том. XXXXVII. - С. 225-229.

12. Прах, С.В. Болезни и вредители косточковых культур и меры борьбы с ними / С.В. Прах, И.Г. Мищенко. - Краснодар: ГНУ СКЗНИИСиВ, 2013 г. - 98 с.

13. Якуба, Г.В. Проявление Alternaria alternata (Fries: Fries) Keissler на яблоне в Краснодарском крае // Materialy VIII Mezinarodni vedecko - practika conference «Veda a technologie: krok do budoucnosti - 2012». - Praha. Publishing House «Education and Science» Dil 29, S. 18-20.

14. Zimmerman, R.H. Fruit plants micropropagation at Beltsville Fruit Laboratory and in North America / R.H. Zimmerman // Rev. Ortoflorofruit. I.t. - 1980. - V. 64, № 3. - P. 241-256.

\section{References}

1. Jurchenko, E.G. Jekologicheskoe obosnovanie sovershenstvovanija fitosanitarnogo menedzhmenta dlja povyshenija ustojchivosti mnogoletnih agrocenozov / E.G. Jurchenko, G.V. Jakuba, S.R. Cherkezova, S.V. Prah, N.A. Holod, I.G. Mishhenko // Nauchnye trudy SKZNIISiV.- Tom 7. - Krasnodar: SKZNIISiV, 2015. - S.167-177. 
2. Dolzhenko, V.I. Fitosanitarnoe rajonirovanie vrednyh dlja sel'skogo hozjajstva organizmov / V.I. Dolzhenko // Agrotehnicheskij metod zashhity rastenij ot vrednyh organizmov: materialy V mezhdunar. nauchn.-prakt. konf. (- Krasnodar, 2011. - S. 24-30.

3. Metody opredelenija boleznej i vreditelej sel'skohozjajstvennyh rastenij. - M.: Agropromizdat, 1987. $-224 \mathrm{~s}$.

4. Metodiki opytnogo dela i metodicheskie rekomendacii SKZNIISiV. - Krasnodar, 2002. - S. 143-176.

5. Dospehov, B.A. Metodika polevogo opyta / B.A. Dospehov. - M.: Agropromizdat, 1985. $-351 \mathrm{~s}$.

6. Pidoplichko, N.M. Gribyparazity kul'turnyh rastenij. Opredelitel' v 3-h tomah / N.M. Pidoplichko. - Kiev: Naukova dumka, 1977. - T. 2. - 299 s.

7. Jurchenko, E.G. Urozhajnost' i kachestvo vinogrado-vinodel'cheskoj produkcii pri primenenii biologizirovannoj zashhity ot oidiuma / E.G. Jurchenko, O.P. Antonenko, N.P. Gracheva, V.N. Nichiporenko // Plodovodstvo i jagodovodstvo Rossii. - 2011. - T. 23. - S. 336-343.

8. Buncevich, L.L. Sovershenstvovanie sistemy proizvodstva vysokokachestvennogo bezvirusnogo posadochnogo materiala plodovyh i jagodnyh kul'tur / Razrabotki, formirujushhie sovremennyj oblik sadovodstva / L.L. Buncevich, M.A. Kostjuk, E.N. Paleckaja. - Krasnodar: GNU SKZNIISiV. - 2011. - S. 254-275.

9. Mishhenko, I.G. Monitoring jentomo - patokompleksov kostochkovyh kul'tur v uslovijah juzhnogo sadovodstva Rossii / I.G. Mishhenko, S.V. Prah. // Agrarnaja Rossija. 2016. - №12. - 7-10.

10. Prah, S.V. Monitoring jentomo-patocenozov kostochkovyh kul'tur kak nauchnaja osnova tehnologii zashhitnyh meroprijatij / S.V. Prah, I.G. Mishhenko // Plodovodstvo i jagodovodstvo Rossii: sbornik nauchnyh rabot. - M.: FGBNU VSTISP, 2017. - T. XLIX. - S. 265-270.

11. Mishhenko, I.G. Izmenenija v strukture mikopatokompleksov plodovyh kul'tur Krasnodarskogo kraja v sovremennyh sredovyh uslovijah / I.G. Mishhenko, G.V. Jakuba // Sovremennye napravlenija ispol'zovanija genofonda kul'turnyh rastenij dlja ustojchivogo sel'skogo hozjajstva. K 115-letiju so dnja rozhdenija akademika VASHNIL M.S. Dunina. Moskva, 2016. - Tom. XXXXVII. - S. 225-229.

12. Prah, S.V. Bolezni i vrediteli kostochkovyh kul'tur i mery bor'by s nimi / S.V. Prah, I.G. Mishhenko. - Krasnodar: GNU SKZNIISiV, 2013 g. - 98 s.

13. Jakuba, G.V. Projavlenie Alternaria alternata (Fries: Fries) Keissler na jablone v Krasnodarskom krae // Materialy VIII Mezinarodni vedecko - practika conference «Veda a technologie: krok do budoucnosti - 2012». - Praha. Publishing House «Education and Science» Dil 29, S. 18-20.

14. Zimmerman, R.H. Fruit plants micropropagation at Beltsville Fruit Laboratory and in North America / R.H. Zimmerman // Rev. Ortoflorofruit. I.t. - 1980. - V. 64, № 3. - P. 241-256. 